\title{
PERTANGGUNGJAWABAN PIDANA TERHADAP PELAKU YANG MELAKUKAN PERBUATAN MENYURUH ANAK SEBAGAI PENGEMIS
}

\author{
Ni Nyoman Ayu Ratih Ganitri, I Nyoman Putu Budiartha, Luh Putu Suryani \\ Fakultas Hukum Universitas Warmadewa, Denpasar-Bali, Indonesia \\ ratihganitri55@gmail.combudiarthaputu59@gmail.com, putusuryani099@gmail.com
}

\begin{abstract}
Abstrak
Anak-anak tidak hanya terlibat aktif sebagai pengemis, tetapi anak balita juga terlibat secara pasif, yaitu anakanak di bawah usia dua tahun digendong dalam kondisi mengenaskan untuk membuat orang lain merasa sedih dan kasihan, sehingga memberi mereka uang. Penelitian ini bertujuan untuk menjelaskan kualifikasi tindak pidana pelaku yang memerintahkan anak sebagai pengemis dan mengkaji pertanggungjawaban pidana bagi pelaku yang melakukan perbuatan memerintahkan anak sebagai pengemis. Penelitian ini menggunakan metode penelitian hukum normatif dengan pendekatan masalah dan konseptual. Sumber data yang digunakan adalah data hukum primer dan sekunder. Pengumpulan data dilakukan melalui studi kepustakaan dengan cara mencatat. Hasil penelitian mengungkapkan bahwa perbuatan mengemis dikategorikan sebagai pelanggaran ketertiban umum sebagaimana diatur dalam Pasal 504 KUHP. Melakukan tindakan menyuruh anak sebagai pengemis dapat digolongkan sebagai kejahatan dan juga sebagai tindakan pelanggaran. Setiap orang dilarang mengeksploitasi anak dalam bentuk apapun sebagaimana diatur dalam Pasal 301 KUHP junto Pasal 76I dan Pasal 88 UU No. 35 Tahun 2014 tentang Perubahan Atas Undang-undang Nomor 23 Tahun 2002 tentang Perlindungan Anak.
\end{abstract}

Kata kunci : Anak, Pertanggungjawaban Pidana, Pengemis

\begin{abstract}
Children are not only actively involved as beggars, but toddlers are also passively involved, where children under the age of two are carried in pathetic conditions to make other people feel sad and sorry, thus giving them money. This study aims to explain the qualifications of criminal acts of perpetrators who order children as beggars and examine criminal liability for perpetrators who commit acts of ordering children as beggars. This study used a normative legal research method with a problem and conceptual approach. Sources of data used were primary and secondary legal data. Data collection was done through a literature study by taking notes. The results of the study revealed that the act of begging is categorized as a violation of public order as regulated in Article 504 of the Criminal Code. Doing the act of ordering children as beggars can be classified as a crime and also as an act of violation. Everyone is prohibited from exploiting children in any form as regulated in Article 301 of the Criminal Code junto Article $76 I$ and Article 88 of Law no. 35 of 2014 concerning Amendments to Law Number 23 of 2002 concerning Child Protection.
\end{abstract}

Keywords: Children; Criminal Liability; Beggars

\section{PENDAHULUAN}

Tindakan memperlaukan anaak sebagai pengemis merupakan yang melanggar hak-hak anak tersebut, yang berdampak buruk terhadap perkembangan anak serta kehidupan anak tersebut. Pembentukan karakter anak sangat penting maka dari itu perlunya perlindungan dari segala kemungkinan yang membahayakan mereka dan masa depan bangsa. Sebagaimana pandangan Paulo Friere tentang kesadaran naif, pada konteks ini, masyarakat memilih untuk memberikan uang kepada pengemis dianggap jalan yang terbaik, dan bukan mencari sumber masalah yang menyebabkan mereka mengemis. Para pengemis pun memanfaatkan kondisi tersebut untuk mendapatkan penghasilan bulanan. Bahkan, ketika dipahami pengemis anak mampu memperoleh uang lebih banyak dibandingkan dengan pengemis dewasa, maka hal tersebutlah yang menjadi dasar pertimbangan orang tua mereka maupun pihak lain untuk memaksa anak menjadi pengemis (I Wayan Sadia dkk, 2017; 2).

Dalam hal ini pengemis anak menjadi kaum proletar, dimana mereka tidak memiliki aset atau modal apapun untuk bisa melakukan pekerjaan, usia yang masih belum cukup untuk bekerja, fisik yang belum mampu bekerja berat dan tidak memiliki keberanian untuk menolak apa yang dikatakan 
atau disuruh orang lain atau kaum borjuis. Kaum borjuis dalam masalah ini yakni orang dewasa atau orang yang lebih tua dari kaum proletar.

Anak sering dijadikan objek untuk mendapatkan penghasilan oleh berbagai pihak ataupun oknum-oknum yang tidak bertanggung jawab. Dengan memanfaatkan tenaga dari anak tersebut, hal ini biasa disebut dengan eksploitasi anak. Melakukan perbuatan menyuruh anak mengemis dapat mengakibatkan bahaya secara fisik, psikologis dan finansial yang dialami oleh anak tersebut.

Peraturan hukum harus diberlakukan ke depan tidak boleh pasang surut, karena hanya dengan diberlakukan ke depan, manusia sebagai agen mampu menentukan pilihan dalam berperilaku (Dewa Gede Atmaja dan Nyoman Putu Budiartha, 2018; 19). Untuk itu, perlu dilakukan upaya perlindungan untuk mewujudkan kesejahteraan anak dengan memberikan jaminan terhadap pemenuhan hakhaknya. Mengenai siapa yang mempunyai kewajiban dan bertanggung jawab terhadap penyelenggaraan perlindungan anak, jawaban singkatnya adalah orang tua, pemerintah dan Negara.

Penelitian terdahulu yang relevan dengan penelitian ini mengungkapkan Pertanggungjawaban pidana pelaku eksploitasi anak secara sengaja demi kepentingan ekonomi sehingga menyuruh anak sebagai pengemis dan pengamen sanksinya diatur dalam Undang-undang Nomor 35 Tahun 2014 tentang Perubahan atas Undang-undang Nomor 23 Tahun 2002 tentang Perlindungan Anak (Julianti, 2020). Cara mengatasi anak jalanan dilaksanakan melalui Peraturan Daerah dan pendekatan kebijakan mulai dari tahap identifikasi sampai penanganan masalah anak jalanan secara serius, dan diberi sanksi bagi yang sengaja memperlakukan anak sebagai pengemis (Isnawat, 2017); (Irawan, 2013). Dari fenomena tersebut maka ingin dilakukan penelitian yang bertujuan untuk menjelaskan kualifikasi perbuatan tindak pidana pelaku yang menyuruh anak sebagai pengemis dan mengkaji pertanggungjawaban pidana bagi pelaku yang melakukan perbuatan menyuruh anak sebagai pengemi

\section{METODE PENELITIAN}

Metode yang digunaka yaitu penelitian hukum normatif yaitu menganalisis kepustakaan berdasarkan bahan hukum yang digunakan. Mengenai bahan hukum yang digunakan yaitu terdiri dari bahan hukum primer, bahan hukum sekunder dan bahan hukum tersier. Pada metode ini menggunakan pendekatan masalah yaitu pendekatan Perundang-undangan yaitu sesuai dengan ketentuan hukum dan norma yang berlaku, pendekatan konseptual yaitu mengacu pada konsep, asas dan teori yang ada kaitannya dengan permasalahan yang dibahas, pendekatan isi. Teknik pengumpulan bahan hukum yang digunakan yaitu studi kepustakaan, dimana teknik ini mempelajari, mencatat dan membaca doktrin-doktrin. Selanjutnya data dianalisis secara kualitatif deskriptif (Sunggono, 2003).

\section{HASIL DAN PEMBAHASAN}

\section{Kualifikasi Tindak Pidana Pelaku yang Melakukan Perbuatan Menyuruh Anaks sebagai Pengemis}

Perbuatan seseorang sebagai pengemis dipandang sebagai tindak pidana. Perbuatan mengemis di tempat umum diatur dalam buku III KUHP yang di kategorisasikan sebagai delik pelanggaran terhadap ketertiban umum. Tindak pidana pengemisan diatur dalam Pasal 504 KUHP. Adapun aturan pidana tentang perbuatan mengemis yang terdapat dalam Pasal 504 menyatakan bahwa Barang siapa mengemis di tempat umum diancam karena melakukan pengemisan, dengan kurungan selamalamanya enam minggu dan Pengemisan yang dilakukan oleh tiga orang atau lebih, yang masingmasing umurnya diatas enam belas tahun, diancam dengan kurungan paling lama tiga bulan. Adapun unsur-unsur dari pasal tersebut meliputi Perbuatan mengemis secara individu atau kelompok., dilakukan dimuka umum dan usia di atas enam belas tahun.

Pasal 504 Kitab Undang-Undang Hukum Pidana, pada pasal ini tidak melarang orang miskin yang minta pertolongan, namun melarang melakukan perbuatan meminta-minta dimuka umum dengan mengharapkan belas kasihan orang-orang sehingga memberikannya uang. Kata pengemis lazim digunakan untuk sebutan bagi orang yang membutuhkan uang, makan, tempat tinggal, atau hal lainnya dari orang yang ditemuinya dengan cara meminta. Berbagai atribut mereka gunakan, seperti pakaian compang-camping dan lusuh, topi, gelas plastik, atau bungkus permen, atau kotak kecil untuk menempatkan uang yang mereka dapatkan dari meminta-minta. Mereka menjadikan mengemis sebagai pekerjaan mereka dengan berbagai macam alasan, seperti kemiskinan dan ketidak berdayaan mereka karna lapangan kerja yang sempit (Dimas Dwi Irawan, 2013; 1). 
Soesilo mendefinisikan minta-minta atau mengemis dapat dilakukan dengan meminta secara lisan, tertulis atau memakai gerak-gerik, termasuk juga dalam kategori pengertian ini adalah menjual lagu-lagu dengan jalan menyanyi main biola, gitar, angklung, seruling, musik serta menyodorkan permainan sepanjang toko-toko dan rumah-rumah yang biasa dilakukan dikota-kota besar. Adapun kriteria seseorang dapat dikatakan sebagai pengemis yaitu antara lain : (1) Menggunakan pakaian yang tidak layak pakai; (2) Mendapatkan uang yang bergantung dari belas kasihan orang lain; (3) Berada di tempat ramai; (4) Menggunakan sesama untuk merangsang belas kasihan orang lain.

Menurut Wildan klasifikasi pengemis dapat dibedakan menjadi 4 jenis pengemis antara lain sebagai berikut:

a. Pengemis dengan anak

"Pengemis dengan anak merupakan pengemis yang membawa anak kandung ataupun pinjaman untuk diikutsertakan dalam mengemis. Biasanya anak tersebut masih berusia balita dan digendong oleh pengemis dewasa".

b. Pengemis anak merupakan pengemis yang dilakukan oleh anak-anak usia 3-17 tahun. Anak tersebut meminta-minta ditempat ramai dengan berharap mendapatkan uang dari belas kasihan orang lain.

c. Pengemis cacat merupakan pengemis yang memiliki keterbatasan fisik sehingga dapat menarik perhatian dan belas kasihan dari orang lain.

d. Pengemis professional merupakan pengemis yang memang mengemis sebagai profesinya untuk mendapatkan pendapatan dengan meminta-minta ditempat ramai.

Dalam KUHP tindak pidana dikategorikan menjadi kejahatan dan pelanggaran. Penetapan tindak pidana kejahatan diatur dalam buku kedua KUHP, sedangkan penetapan tindak pidana pelanggaran diatur dalam buku ketiga KUHP. Dalam kasus eksploitasi anak untuk menjadi pengemis merupakan suatu tindakan kejahatan dimana didalamya terdapat unsur perbuatan yang memang pantas untuk dihukum di hadapan hukum sesuai dengan peraturan yang ada.

Tindak kejahatan juga dikenal dengan adanya kesengajaan dan juga kealpaan dimana dalam tindakan eksploitasi ini termasuk kedalam kesengajaan. Hal ini tampak adanya kesengajaan dari orang tua yang menyuruh anaknya melakukan perbuatan mengemis termasuk kedalam kategori perbuatan tindak pidana eksploitasi terhadap anak demi suatu kepentingan pribadi. Karena keterbatasan ekonomi dan susahnya mencari pekerjaan hal tersebut yang menyebabkan orang tua menyuruh dan membiarkan anaknya untuk turun ke jalanan demi mencari uang. Dalam tindakan eksploitasi dimana menyuruh anak mengemis dapat digolongkan sebagai tindakan kejahatan. Eksploitasi anak untuk dijadikan pengemis merupakan suatu tindak pidana kejahatan dimana terdapat peraturan perundangundnagan yang mengatur bahwa anak-anak harus mendapatkan perlindungan dan pengawasan dari orang tua mereka serta bagi mereka yang mencoba untuk melakukan tindakan eksploitasi pada anak akan dikenakan sanksi berupa denda maupun penjara sesuai dengan tindak pidana yang mereka lakukan.

Secara sosiologis, pelanggaran adalah demontrasi atau perilaku yang diajukan oleh individu yang bertentangan dengan kualitas yang ada di negara yang telah maju dalam hukum dan ketertiban. Alasan pelanggaran dapat terjadi karena data yang terbatas atau tidak adanya klarifikasi hukum dan ketertiban. Perbuatan menyuruh anak mengemis juga merupakan sebuah tindakan pelanggaran. Eksploitasi anak menjadi pengemis merupakan suatu tindakan pelanggaran yaitu pelanggaran atas hak asasi manusia (Nashriana, 2011;2).

Pasal 2 ayat (3) dan ayat (4) Undang-Undang Nomor 4 tahun 1979 Tentang Kesejahteraan Anak, menegaskan bahwa anak berhak atas pemeliharaan dan perlindungan, baik semasa dalam kandungan maupun sesudah ia lahir, anak berhak atas perlindungan terhadap lingkungan hidup yang dapat membahayakan atau menghambat pertumbuhan secara wajar. Pelaku yang melakukan perbuatan menyuruh anak sebagai pengemis termasuk sebuah pelanggaran terhadap hak asasi manusia. Pelaku dengan sengaja memanfaatkan anak untuk bekerja dan mendapatkan penghasilan dengan cara mengemis sehingga hak anak tidak dapat dipenuhi. 


\section{Pertanggungjawaban Pidana Bagi Pelaku yang Melakukan Perbuatan Menyuruh Anak Sebagai Pengemi}

Sanksi pidana adalah suatu hukuman sebab akibat, sebab adalah kasusnya dan akibat adalah hukumnya, orang yang terkena akibat akan memperoleh sanksi baik masuk penjara ataupun terkena hukuman lainnya dari pihak berwajib. Sanksi pidana pada dasarnya merupakan suatu penjamin untuk merehabilitasi pelaku dari kejahatan tersebut, namun tidak jarang bahwa sanksi pidana diciptakan sebagai suatu ancaman dari kebiasaan manusia itu sendiri (Andrisman, 2009; 8). Sanksi pidana adalah suatu jenis sanksi yang bersifat nestapa yang diancamkan atau dikenakan terhadap perbuatan atau pelaku perbuatan pidana atau tindak pidana yang dapat mengganggu atau membahayakan kepentingan umum. Pemberian sanksi terhadap pelaku merupakan suatu bentuk upaya perlindungan anak karena dengan adanya ancaman hukuman atau sanksi, tindakan pelanggaran atas hak perlindungan anak dapat berkurang. Perlindungan anak di bawah umur dua belas tahun dari pekerjaan mengemis atau pekerjaan berbahaya yang diatur dalam pasal 301 KUHP yang berbunyi barang siapa memberikan atau menyerahkan kepada orang lain, seorang anak yang umurnya kurang dari dua belas tahun dan yang di bawah kuasanya yang sah, dalam hal diketahuinya bahwa itu akan dipakai untuk atau pada waktu mengemis, atau dipakai menjalankan kemudi yang berbahaya atau melakukan pekerjaan yang berbahaya atau dapat merusak kesehatan, di hukum dengan hukuman penjara selama-lamanya empat tahun (Prodjodikoro, 2003; 126).

Anak yang sengaja dijadikan pengemis akan berdampak sangat buruk bagi anak. Larangan eksploitasi ekonomi terhadap anak diatur di dalam Pasal 76I Undang-Undang Perlindungan Anak yang menyatakan setiap orang dilarang menempatkan, membiarkan, melakukan, menyuruh melakukan, atau turut serta melakukan eksploitasi secara ekonomi atau seksual terhadap anak.

Pasal 88 Undang-undang Perlindungan Anak menyatakan bahwa setiap orang yang mengeksploitasi ekonomi atau seksual anak dengan maksud untuk menguntungkan diri sendiri atau orang lain, dipidana dengan pidana penjara paling lama 10 tahun atau denda paling banyak $\mathrm{Rp} 200.000 .000,00$.

Ancaman sanksi pidana terhadap perorangan maupun kelompok dimaksudkan agar mencegah terjadinya tindakan pidana kepada anak yang akan memberikan efek jera kepada si pelaku maupun bagi pihak lain agar tidak meniru perbuatan yang sama. Ancaman pidana adalah salah satu dari upaya penegakan hukum dan hak asasi manusia untuk memberikan perlindungan yang memadai terhadap anak dari segala bentuk kekerasan baik fisik, psikologis, seksual maupun penelantaran termasuk jenisjenis perbuatan lainnya, mengingat anak termasuk kelompok yang sangat rentan mengalami berbagai perlakuan yang dapat menghambat pertumbuhan dan perkembangan kehidupannya.

Apabila pelaku yang melakukan perbuatan tersebut merupakan orang tua dari anak yang menjadi korban maka konsekuensi hukuman yang diberikan harus lebih berat dari orang biasanya, sehingga tidak akan ada niat untuk melakukan perbuatannya kembali.

Terlibatnya anak dalam kegiatan ekonomi juga karena adanya dorongan untuk membantu meringankan beban orang tua, juga keinginan menikmati hasil usaha kerja, merupakan faktor-faktor motivasi pekerja anak. Namun, motivasi utama yang mendesak anak-anak untuk bekerja adalah tuntutan dari orang tua yang bertujuan untuk mendapatkan keuntungan dengan memperoleh pemasukan lebih bagi keluarga (Megalia Tifani Piri, 2013; 28). Anak yang bekerja dikelompokan menjadi 2 yaitu:

1. Anak yang berkerja adalah anak melakukan pekerjaan karena membantu orang tua, latihan keterampilan dan belajar bertanggung jawab, contohnya membantu mengerjakan tugas-tugas di rumah, membantu pekerjaan orang tua di ladang dan lain-lain. Anak melakukan pekerjaan yang ringan tersebut dapat dikategorikan sebagai sosialisasi dan perkembangan anak menuju dunia kerja.

2. Pekerja anak adalah anak yang melakukan segala jenis pekerjaan yang memiliki sifat atau intensitas yang dapat mengganggu pendidikan, membahayakan keselamatan, kesehatan serta tumbuh kembangnya dapat digolongkan sebagai pekerja anak.

Dalam pasal 45 KUHP disebutkan: Dalam hal penuntutan pidana terhadap orang yang belum dewasa karena melakukan suatu perbuatan sebelum umur enam belas tahun, hakim dapat menentukan: memerintahkan supaya yang bersalah dikembalikan kepada orang tuanya, walinya atau pemeliharanya, tanpa pidana apa pun; atau memerintahkan supaya yang bersalah diserahkan kepada pemerintah tanpa pidana apapun, jika perbuatan merupakan kejahatan atau salah satu pelanggaran 
berdasarkan pasal-pasal 489, 490, 492, 496, 497, 503-505, 514, 517-519, 526, 531, 532, 536, dan 540 serta belum lewat dua tahun sejak dinyatakan bersalah karena melakukan kejahatan atau salah satu pelanggaran tersebut di atas, dan putusannya telah menjadi tetap; atau menjatuhkan pidana kepada yang bersalah.

Jadi terdapat perbedaan antara bentuk sanksi pidana terhadap perbuatan pidana oleh orang yang telah dewasa dengan orang yang belum dewasa. Jika perbuatan pidana yang dilakukan oleh orang yang telah dewasa maka akan dikenakan sanksi pidana sesuai pasal-pasal yang terdapat di dalam KUHP tergantung dari jenis pidana yang dilakukan. Sedangkan sanksi pidana untuk anak yang belum dewasa hanya dapat dikenakan pidana sesuai dengan KUHP pasal 45. Perilaku kenakalan yang dilakukan oleh anak walau terkadang sama dengan seperti kejahatan yang dilakukan orang dewasa, bukan berarti sanksi yang diberikan juga sama.

\section{SIMPULAN DAN SARAN}

\section{Simpulan}

Berdasarkan hasil analisis data, penelitian ini mengungkapkan tindakan eksploitasi dimana menyuruh anak sebagai pengemis dapat digolongkan sebagai tindakan kejahatan. Melakukan perbuatan menyuruh anak sebagai pengemis juga merupakan suatu tindakan pelanggaran yaitu pelanggaran atas hak asasi manusia. Menjadikan anak sebagai pengemis merupakan salah satu bentuk penghianatan terhadap pemenuhan hak-hak anak tersebut. Sanksi pidana terhadap pelaku yang melakukan perbuatan menyuruh anak sebagai pengemis yaitu diatur dalam Pasal 301 KUHP junto Pasal 76I junto Pasal 88 Undang-undang Nomor 23 Tahun 2002 tentang Perlindungan Anak dengan diberikan sanksi pidana dengan ancaman pidana penjara adalah paling lama sepuluh tahun, dan denda paling banyak Rp. 200.000.000

\section{Saran}

Dari simpulan penelitian, adapun saran peneliti yaitu diharapkan bagi pemerintah untuk selalu melakukan kegiatan razia dan pemantauan terhadap pengemis serta memberikan sanksi yang tegas kepada pelaku yang melakukan perbuatan menyuruh anak sebagai pengemis. Bagi orang tua seharusnya tidak merampas hak anak termasuk mempekerjakannya sebagai pengemis, melainkan seharusnya mampu bertanggung jawab kepada anaknya seperti memenuhi kebutuhannya, melindungi dari segala ancaman, serta menjamin tumbuh kembang anak.

\section{DAFTAR PUSTAKA}

Andrisman, T. (2009). Asas-Asas dan Dasar Aturan Hukum Pidana Indonesia. Unila. Bandar Lampung.

Atmaja, I. D. G. (2018). Teori-Teori Hukum. Setara Press.

Irawan, D. D. (2013). Pengemis Undercover Rahasia Seputar Kehidupan Pengemis. Titik Media Publisher.

Isnawat. (2017). Tinjauan Yuridis terhadap Peranan Pemerintahan Daerah dalam Penertiban Anak Jalanan di Kota Samarinda. Jurnal Ilmiah Hukum De’Jure, 2(2), 284-298.

Julianti, F. (2020). Pertanggungjawaban Pidana Terhadap Orang Tua yang Menjadikan Anak Kandung sebagai Pengemis dan Pengamen. Jurist-Diction, 3(5), 1713-1728.

Nashriana. (2011). Perlindungan Hukum Bagi Anak di Indonesia. PT Raja Grafindo Persada.

Piri, M. T. (2013). Perlindungan Hukum Terhadap Tindakan Eksploitasi Anak (Kajian UndangUndang Nomor 23 Tahun 2002). Lex Administratum, 1(2), 28.

Prodjodikoro, W. (2003). Tindak-Tindak Pidana Tertentu. Refika Aditama.

Sadia, I. W., Suma, K., \& Supir, I. K. (2017). Mengapa Siswa Sekolah Dasar Menggepeng ? ( Studi Kasus Desa Muntigunung, Karangasem, Bali ). 2.

Sunggono, B. S. B. (2003). Metode Penelitian Hukum Jakarta. PT Raja Grafindo Persada. 